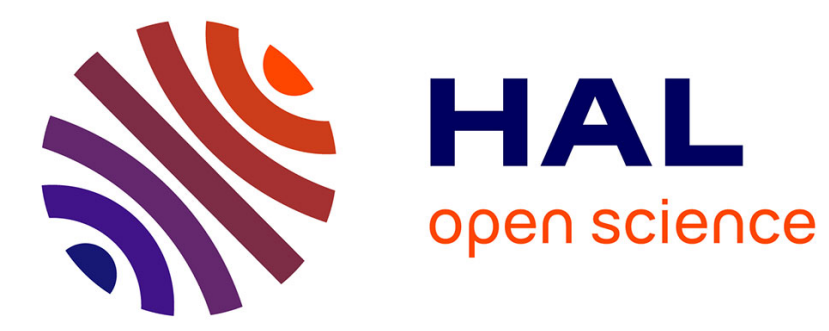

\title{
South Korean System of Innovation: From Imitation to Frontiers of Technology, Successes and Limitations
}

\author{
Aouatif El Fakir
}

\section{To cite this version:}

Aouatif El Fakir. South Korean System of Innovation: From Imitation to Frontiers of Technology, Successes and Limitations. Mostafa Hashem Sherif, Tarek M. Khalil. Management of Technology Innovation and Value Creation, pp.275-292, 2008, 978-981-279-053-8 10.1142/9789812790545_0017 . hal-01347728

\section{HAL Id: hal-01347728 \\ https://hal.science/hal-01347728}

Submitted on 21 Jul 2016

HAL is a multi-disciplinary open access archive for the deposit and dissemination of scientific research documents, whether they are published or not. The documents may come from teaching and research institutions in France or abroad, or from public or private research centers.
L'archive ouverte pluridisciplinaire HAL, est destinée au dépôt et à la diffusion de documents scientifiques de niveau recherche, publiés ou non, émanant des établissements d'enseignement et de recherche français ou étrangers, des laboratoires publics ou privés. 
Chapter XX

\title{
South Korean System of Innovation: From Imitation to Frontiers of Technology, Successes and Limitations
}

\author{
Aouatif El Fakir ${ }^{1}$ \\ Institut de Recherche Internationale, Dauphine University, Paris, \\ France
}

\begin{abstract}
In this chapter, we use an analytical framework based on the "national system of innovation" approach to understand how South Korea acquired technological capabilities, increased the effectiveness of its national system of innovation and became a major player in many hightech industries.
\end{abstract}

\section{Introduction}

Some developing countries have emerged as serious competitors in new areas of technology. How did they acquire the necessary capabilities to use technology and even to develop it? And how did they make their systems of innovation more sophisticated?

This chapter will examine the case of South Korea to understand how it has acquired technological capabilities and increased the effectiveness of its national system of innovation to become a major player in many high-tech industries.

\footnotetext{
${ }^{1}$ The Author is grateful to Mostafa Hashem Sherif for the support received in the preparation of the manuscript.
} 
We use an analytical framework based on the "national system of innovation" approach to clarify this process. We assume that countries acquire capabilities to produce new goods, services and technologies through interactive learning spaces (ILS). The effectiveness of these spaces depends on how technologies, institutions and organisations evolve simultaneously.

Section 1 contains a critical review of the literature on the acquisition of technological capabilities. In section 2 , we present the analytical framework based on the national system of innovation approach. In section 3, we use this framework to examine the case of South Korea. We conclude with a discussion on developing countries in terms of the relationship between technology and development.

\section{The Acquisition of Technological Capabilities in Developing Countries: Theories and Approaches}

The study of technology in developing countries started in the 1960's. Until the mid seventies, the main corpus of literature was called the Theory of Technological Dependency. This theory considers that technologies that are already developed elsewhere should not be reinvented but must be exploited under the following two conditions: the technology should be appropriate to a country's needs and it should be available at a reasonable cost. The theory also highlights the role of foreign investments and multinationals companies in the transfer of technology (Gerschenkron, 1962; Helleiner 1975).

From the mid seventies to the mid eighties, many scholars assumed that indigenous science can be more responsive to national needs than technology imports. The effectiveness of the National System of Science, Technology and Innovation (S\&T\&I) depends on some conditions like long term investments, efforts to accumulate knowledge, and skills and know-how, selection of the right R\&D fields, effective institutional support and international (Jones, 1971; Cooper, 1973; Herrera, 1973; Sagasti, 2004).

The 1980's witnessed the emergence of the Theory of Technological Capabilities. It stipulates that imported technology cannot be used if it 
does not match the scale, skills and material needs of the new environment. Therefore, developing countries can not take advantage of imported technologies without a threshold of technological capabilities (Bell, 1984; Dahlman, Ross-Larsonn and Westphal, 1987; Fransman and King, 1984; Katz, 1987; Lall 1987).

At the end of the 1980's, the Windows of Opportunity Theory assumed that co-evolution of technology, institutions and organisations is essential for catching up and growth. The time needed to learn and the perspectives for growth depend on the technology. Developing countries must identify clearly the current stage of the technology and acquire the suitable combination of productive and institutional infrastructure, scientific/technical knowledge and experience. The cost of these components changes in each stage of the technology life cycle. It is lower in the emerging and mature stages of technology and higher in the growth phase (Perez and Soete, 1988; Perez, 2001).

While all these approaches and theories have illuminated many fundamental aspects on the technology transfer to developing countries, they lack an overall vision of how developing countries can acquire capabilities to use, adapt, improve and even develop technologies.

As a consequence, we propose to use the National System of Innovation (NSI) approach, because it could help to identify the actors and the mechanisms that determine the success of innovation and technological development processes. This approach emerged in the 1980 's and the 1990's as an analytical framework in developed countries. It assumes that innovations result from interactive learning processes and the co-evolution of technologies, institutions and organisations. Here, innovations mean using new technologies, adapting, improving and even developing them (Lundvall, 1992; Nelson, 1993).

\section{The National System of Innovation (NSI) Approach}

According to NSI approach, innovations (not inventions) occur within a specific system in which stakeholders interact and learn from each other to take advantage of technological and market opportunities. 
Interactive learning is the main process leading to innovation because it enables individuals and organisations to acquire new knowledge and new skills to improve their performances, to seize opportunities and to face pressures (Lundvall, 1992; Mckelvey, 1997) Moreover, this approach emphasizes the uncertainty of the innovation process and the need for an appropriate institutional framework (Nelson and Winter, 1982; Saviotti, 1997).

Although the NSI approach highlights systemic and dynamic aspects of the innovation, it has some limitations. It is based on the observation of sophisticated and complex innovation systems in developed countries. As a consequence, we had to adapt it to the context of developing countries because of the following reasons. First, the behaviour and objectives of the corresponding organisations and institutions differ. Second, the NSI indicators for developing countries deal with systems under construction. Finally, developing countries are operating in the context of a globalized R\&D where technological alliances can play a significant role in technology acquisition.

Empirical studies of NSIs in developing countries, such as the comparative study of Dahlman and Nelson (1995), have confirmed that the macroeconomic environment and incentives regime determine technological and economic performance. In addition, resources like appropriate human capital, foreign technologies, industrial infrastructure, public support and funding are crucial for the acquisition of technological capabilities.

Arocena and Sutz's theoretical works about innovation in developing countries highlighted that developing countries lack "interactive learning spaces" which are "interactive activities and processes where individuals and organisations generate, transfer and use systemically knowledge to enhance their ability to learn and to resolve problems." (Arocena and Sutz, 2002). These interactive learning spaces (ILS) facilitate the resolution of pressing problems of production by the encounter of actors owning the problems with "knowledge" actors

So, we assume here that these ILS cannot emerge if there are no incentives and pressures on firms to be more competitive and if they do not have the resources to participate in processes to generate, transfer and use knowledge. We also assume that in these learning spaces, firms 
acquire new technological capabilities and the national system of innovation emerges. As these spaces become systemic, firms strengthen their technological capabilities and the NSI becomes more sophisticated and effective.

\section{The Acquisition of Technological Capabilities in South Korea}

South Korea achieved a very fast development process in the last forty years and emerged as a competitive supplier in many medium and high tech industries. First, we note the incentives/pressures that pushed Korean firms to enter in ILS. We then examine the resources they used to resolve production and innovation problems. We will observe how spaces, resources and capabilities have evolved from 1960 until now. Our study is based on the works of Kim $(1980,1993,2000)$, Westphal, Rhee and Pursell (1985), Westphal, Kim and Dahlman (1985), Kim and Yi (1997), Kim and Lee (1987) and Lim (1999). Table 1 provides figures on the growth the GDP (gross domestic product) and GDP per capita in South Korea from 1960 to 2000. Table 2 shows the evolution of exports from 1966 to 2000. It seen that, in addition to their dramatic growth over the last four decades, their technological content has continuously progressed to higher values.

The South Korean technological, industrial and economic progress has gone through 4 stages. In the 1960's, South Korea was oriented to import substitution before switching to export promotion. This phase witnessed the set up and strengthening of production capabilities ${ }^{2}$. The 1970's was the period of increasing exports, the establishment of heavy industries and the development of investment capabilities ${ }^{3}$. High-tech industries and local R\&D activities emerged during the 1980's. In the third phase, industries and activities were strengthened during the 1990's

\footnotetext{
${ }^{2}$ Production capabilities include the supervision of production facilities, raw materials control, production planning, quality control, production problems resolutions, process and product adaptation, facilities repairing and maintenance and marketing (Westphal Rhee and Pursell, 1985).

3 Investment capabilities include labour force training, feasibility studies, projects implementation, management and engineering, specific studies, basic and specific engineering and purchasing. Ibid.
} 
despite the financial crisis and some industrial and institutional failures. In the current phase, which started in 1997, South Korea has undertaken many reforms which put it on a new growth virtuous spiral, but some limitations prevent it from becoming a knowledge and innovation economy.

Table 1: GDP and GDP per capita of South Korea 1960-2000. 


\begin{tabular}{|l|l|l|}
\hline Year & $\begin{array}{l}\text { GDP } \\
\text { (current } \\
\text { billion. US\$) }\end{array}$ & $\begin{array}{l}\text { GDP per } \\
\text { capita, } \\
\text { Purchasing } \\
\text { Power Parity } \\
\text { (current } \\
\text { international } \\
(\$)\end{array}$ \\
\hline 1960 & 3.9 & 155 \\
\hline 1965 & 3.0 & 108 \\
\hline 1970 & 8.9 & 275 \\
\hline 1975 & 21.5 & 599 \\
\hline 1980 & 63.8 & 1632 \\
\hline 1985 & 96.6 & 2290 \\
\hline 1990 & 263.8 & 5893 \\
\hline 1995 & 517.1 & 10850 \\
\hline 2000 & 511.7 & 9763 \\
\hline
\end{tabular}

Source: World Bank.World Development Indicators Database.

Table 2: Structure of exports of South Korea 1966-2000

\begin{tabular}{|l|l|l|l|l|l|}
\hline Type of Export (\%) & 1966 & 1976 & 1987 & 1995 & 2000 \\
\hline Primary products & 37.9 & 10.1 & 6.4 & 3 & 2 \\
\hline Resources based manufactures & 12.5 & 6.2 & 3.4 & 7 & 11 \\
\hline Low tech manufactures & 41.8 & 55.5 & 52.3 & 20 & 17 \\
\hline Medium tech manufactures & 0.4 & 4.4 & 13.7 & 35 & 33 \\
\hline High tech manufactures & 1.3 & 6.7 & 21.8 & 30 & 36 \\
\hline
\end{tabular}

Source: Calculated from international trade statistics, SITC Rev.2. OECD. 2005.

\subsection{Keys of success}

This success cannot be objectively explained without speaking about the U.S. assistance during the cold war and the major role of Korean government nationalism and culture. In fact, during 1950's, American aid was vital for the reconstruction and industrialization of South Korea after Korean War. Until 1961, $70 \%$ of public investments were funded by U.S. aid (military aid from 1953 to 1961 amounted to 1561 million U\$) (Toussaint, 2006). In the 1960's, South Korea firms supplied the U.S. military in the region with construction services, machinery and some 
finished products (tire, wood). This helped them improve their management, organizational and technical skills (Westphal Rhee and Pursell, 1985).

The U.S. has remained an important source of technology. Moreover, thanks to Korean Diaspora in the U.S, joint ventures with U.S. firms and research structures allowed South Korean firms to assimilate new technologies, especially in electronics, particularly during the 1980's.

During the totalitarian regime (1961-1987), the South Korean government pursued an active industrial development policy which was continued after the democratic transition in 1987. Reforms of the agricultural regime, investments in infrastructure and education, public funding, subsidies, tax incentives and strong protectionism were the main tools that the South Korean government used to achieve technological and industrial development.

South Korean nationalism and culture played an important role, particularly in the early stages (Koo, 1995). According to Song (1997), new Confusionism in South Korea encouraged personal achievement (education and discipline), family values, patriotism, harmony and community spirit.

We will now highlight the ILS that improved technological capabilities of Korean firms and lead to the production of new goods and the use of new technology in each period. Our objective here is to clarify the link between ILS and the technological and industrial development of South Korea.

\subsection{The 1960's: The acquisition of production technological capabilities}

In this decade, South Korea had three major handicaps: a small local market, lack of natural resources and low technological capabilities to compete locally or abroad. The Korean government switched rapidly from import substitution to export promotion to encourage the acquisition of production capabilities in many new industries. Public incentives (subsidies, domestic market protection, fiscal incentives and so on) and attractive market opportunities encouraged Korean firms to acquire technological capabilities even in industries in which they had no 
competitive advantage. In general, the technology in these industries was mature except for electronics.

Korean firms took also advantage of qualified workers who were able to assimilate new knowledge and to acquire new skills rapidly. They benefited from available foreign technologies in the form of capital goods, turnkey plants, technical assistance and licences. Large firms (chaebols or Chaebols, please be consistent throughout the paper) benefited from attractive financial terms from Korean banks. Lastly, the government set up many measures to increase the bargaining power of Korean firms.

To acquire technological capabilities, Korean firms entered deliberately in many ILS that involved different actors according to the production process and scale as well as the size of the firms.

In small batch industries (shipbuilding, machinery), large firms favoured capital goods, licences imports and technical assistance. They were involved in interactive learning spaces with foreign suppliers and experts through training and in situ technical assistance. Korean engineers and technicians learned how to manufacture effectively large quality of quality products with varying technical specifications. Small firms applied imitative reverse engineering. In addition, they interacted with local users to improve their copies of foreign products. Lastly, in new industries, technical staff moved from the pioneer firms to latecomers and interacted with their inexperienced personnel. Thus, foreign technologies were rapidly disseminated.

In large batch industries (electronics, automobile), large and small firms set up ILS with foreign suppliers of sophisticated products to acquire knowledge through training and technical assistance. Small firms preferred imitative reverse engineering of simple products. Foreign technologies have been disseminated in the same way as in small batch industries.

In industries using process production (chemicals, cement, pharmaceutical), firms purchased turnkey plants to acquire initial production capabilities. Korean technical personnel entered in interactive learning spaces with foreign technical experts to assimilate technology and to perform production, maintenance and repair operations. 
In summary, in this period, the learning spaces were dominated by foreign sources of technology. Large firms imported technologies to acquire production capabilities and small firms preferred imitative reverse engineering. However, all tried to improve their capabilities to be more autonomous and to enhance quality and sophistication to go to next stages.

\subsection{The 1970's: The emergence of innovation capabilities}

During the 1970s, the Korean companies improved rapidly their technological capabilities in production and in product design. Interactions with foreign customers enhanced the know-how of local companies and new technologies, some mature and some growing, were acquired.

The output of large production facilities set-up in many industries to achieve economies of scale economies was larger than the local market could absorb, so Korean firms had to open new markets. To have competitive exports, they had to reduce costs, differentiate products and improve their quality. A large percentage of Korean firms worked under Original Equipment Manufacturing (OEM) agreements and had to meet tight specifications. To do so, they had to acquire more sophisticated engineering capabilities. Also, OEM relationships constituted precious sources of information about international markets.

Finally, the South Korean government provided attractive incentives in heavy industries like chemicals, the automobile industry, steel or shipbuilding.

The combination of all these factors resulted in a more technically qualified labour force. Korean firms could then import or assimilate more complex and newer technologies. Even while they continued to use some of the old spaces, Korean firms could also engage in new interactive learning spaces in the following manner.

First, in many established industries, new firms hired the technical personnel of pioneering firms to benefit from their experience and skills. Moreover, the new entrants avoided the inherent risks of technology selection by taking advantage of adaptations achieved by the pioneers. 
Secondly, large Korean companies involved in OEM agreements entered in a specific interactive learning space with their costumers.

Lastly, large Korean firms continued to import sophisticated and complex technologies through specially licences. Hence, interactive learning space between licence suppliers (especially Japanese) and Korean firms aimed at acquiring production capabilities in new technologies and/or design capabilities in established areas. In short, the acquisition and mastery of production technologies progressed during this phase through "learning by doing" and "learning by using" as well as by adaptations of the foreign technologies. The mobility of qualified workers and other formal and informal mechanisms made the dissemination of technologies easier. Simultaneously, the acquisition of design capabilities continued through the transfer of foreign knowledge, NSI was more and more embedded in economic system, interactions between actors became more systemic and Korean firms reinforced their international competitiveness and enhanced the range of their products.

\subsection{The 1980's: The emergence of high-tech industries and the expansion of $R \& D$}

At the beginning of the 1980 's, South Korea faced a dramatic change. The economic crisis pressed the U.S. and Europe to set up protectionist measures against new industrialised countries. South Korea also lost its competitive advantage in labour intensive industries as real wages increased. Moreover, foreign suppliers of technology became reluctant to supply it to their Korean competitors. Lastly, imitative reverse engineering became more difficult as South Korea tightened regulations regarding the protection of intellectual property. Many emerging hightech industries, however, provided new opportunities. Among them, South Korea chose semiconductors, optical fibre, robotics, computer and aircraft.

During this decade, large Korean firms had to increase their reliance on indigenous resources in R\&D with government assistance through exportations subsidies, technology monitoring, financial assistance and so on. Yet, the supply of highly qualified engineers and scientists at this time was not adequate for the needs. To fill this gap, Korean firms 
attracted Koreans expatriates (from the United States, Europe and Japan). Korean-American engineers and scientists provided the necessary bridges with foreign experts on specific R\&D projects. Moreover, large firms like Samsung, Hyundai and LG invested in foreign technological outposts to monitor technological changes and work with foreign firms and R\&D institutes within technology clusters. Korean foreign subsidiaries and outposts contributed to the dissemination of foreign knowledge and know-how particularly in electricity, electronics and chemicals. All these interactive learning spaces, particularly those that involved Korean and U.S companies, were extremely beneficial in leading-edge technologies such as semiconductors, computer and biotechnology.

In many industries, such as robotics and computers, companies (notably Chaebols) continued to use their usual ILS. New interactive learning spaces involved Chaebols and multinationals firms (MNFs) through joint ventures. The latter were interested in technological cooperation with Korean firms with large production capabilities. While Korean firms aimed to strengthen their innovative capabilities.

In this decade, Korean companies started to work with government research institutes (GRIs). National R\&D Projects (NRP) and Industrial Base Technology Development Projects (IBTDP) set up by the Korean government involved the GRIs and firms in selected technologies.

In short, during the 1980s, Korean companies (particularly Chaebols) moved from reverse engineering to international cooperation and local $\mathrm{R} \& \mathrm{D}$ to acquire the knowledge associated with the emerging industries. Reverse engineering and internal $R \& D$ was for relatively simple technological tasks in robotics, computers at the beginning. Interactions with foreign companies and indigenous R\&D structures were reserved for more complex cases. The ILS helped to establish new industries to replace those that lost their competitive edge and to take advantage of new opportunities. The NSI became more autonomous, innovations more endogenous. As a consequence, the Korean economy was radically transformed in this critical decade. 


\subsection{The 1990's: The expansion of high-tech industries and the strengthening of innovation capabilities}

The Korean slowdown during the 1990's had many reasons, both internal and external. Nevertheless, after the financial crisis, favourable conditions accelerated Korean recovery. Foreign investors' confidence was re-established, many large companies were restructured and currency was re-stabilized. Moreover, favourable global demand, and information and communication technology expansion encouraged Korean firms to increase their efforts towards more creativity and inventiveness in order to take advantage of new innovation-intensive industries.

In addition, large investments in basic research in universities, venture capital availability, attractive public incentives and the needs of more flexible firms in many industries encouraged the setting-up of hightech and innovative SMEs.

By and large, Korean firms achieved internal R\&D and kept their relationships with Korean diaspora to improve their innovative capabilities. They also maintained cooperation with MNFs and GRIs. In addition, the government continued to support firms through subsidies, financial assistance and so on. Lastly, in the case of more complex capabilities, Korean companies increased their patent portfolio to enhance their negotiation position with international parties through cross-licensing and similar intellectual protection schemes.

Korean firms, notably Chaebols, reorganized themselves to encourage new "creative spaces." For example, to stimulate innovation, employees with new ideas could set up experimental spaces involving persons of various domains to find profitable projects in the short and medium terms.

Furthermore, outsourcing needs of Chaebols strengthened semipermanent relations between them and their SME suppliers of components and machinery. This cooperation resulted in cost reduction, and improved the design and production capabilities for complex technologies.

Also, Korean SMEs were involved together in many interactive learning spaces through R\&D cooperation, common equipment and 
inputs purchasing, common marketing in order to improve their efficiency and quality.

Korean companies continued to be involved with GRIs in new hightech industries, such as artificial intelligence, advanced robotics and so on. Lastly, Chaebols kept interactive learning spaces through joint ventures with MNFs to strengthen their innovative capabilities.

In this stage, ILS led to the acquisition of more complex engineering and innovative capabilities in order to keep pace with technology frontiers and to generate new technologies in specific industries.

Figure 1 summarizes the technological catch-up process of South Korea.

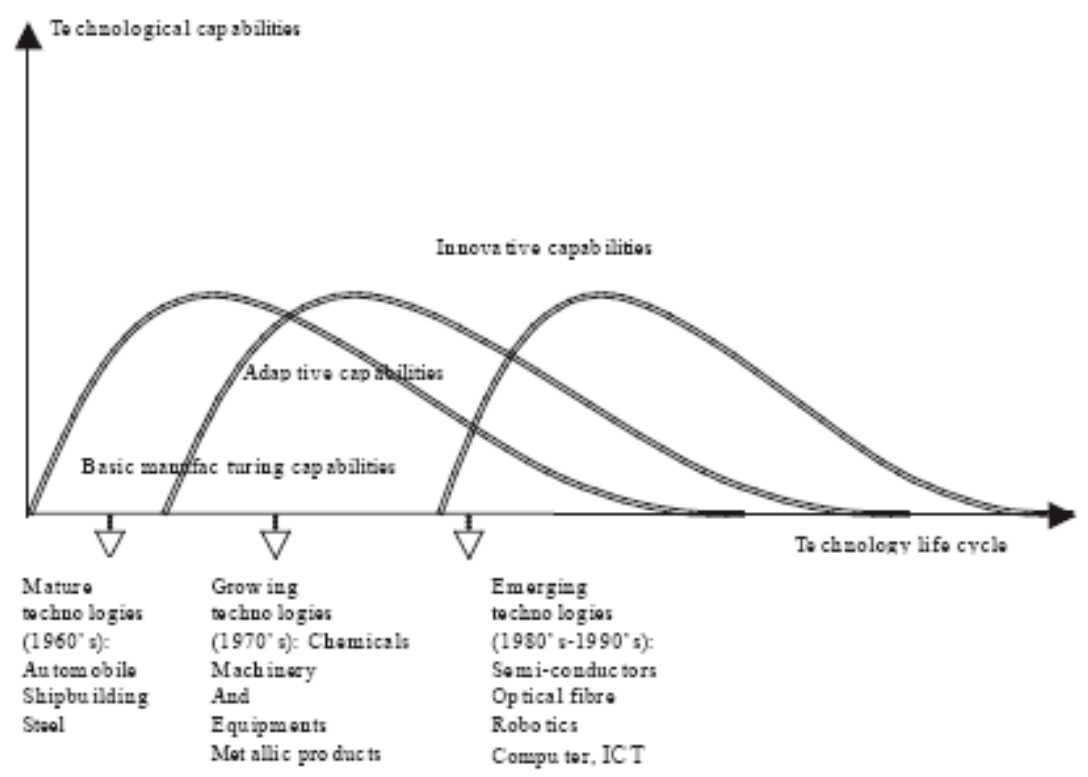

Figure 1: Technological development process of South Korea

\section{The 2000's: South Korean System of Innovation limitations}

Many studies and reports in the 2000's have indicated that South Korea is not a producer of radically new knowledge. Chaebols do not have enough capabilities to innovate radically and there are only few technological SMEs. Basic and applied researches are not promoted 
enough and scientists and researchers are not equally distributed between GRIs and universities (Kim, 2000; OECD, 2005).

To fill the gaps of its system of innovation, OECD recommended that South Korea focus on three major areas of improvements. First, basic research, especially within universities, must be strengthened to increase the chances of new discoveries and to develop new technologies. More interactions between different innovation actors (firms, GRIs, universities) are also required. Moreover, scientific and technological cooperation with others countries must be intensified to take advantage of their previous experience. Second, education policy must be reformed to diversify higher education and develop creative and high quality expertise in strategic areas. Third, industrial policy must lead to a more balanced structure between SMEs and Chaebols and to more intensive learning and innovation through more business services, venture capital development, support networks, enhancement of creativity culture and so on.

In recent years, Korea has followed many of these recommendations. In fact, R\&D expenditures reached $2.63 \%$ of GDP in 2003 (24321.3 million U.S.\$), higher than the OECD average. New R\&D public programs and higher universities budgets (to intensify basic research) lead to the rise of public expenditures. Moreover, the number of researchers reached 6.2 per 1000 workers, which is close to the OECD average in 2002 (OECD, 2006). Furthermore, in the early the 2000's, South Korean government restructured the national system of innovation to encourage creativity an innovation such as upgrading academic and industrial laboratories.

Consequently, South Korean scientific and technological outputs increased significantly in recent years. As shown in Table 3, patent applications and patents granted to South Korean inventors increased dramatically between 1995 and 2005. The percentage of high- and medium tech exports rose respectively $36.1 \%$ and $32.2 \%$ of the total South Korean exports. In contrast, low and medium-low tech exports declined to respectively $11.4 \%$ and $20.3 \%$ (OECD, 2006; STAN database). 
Table 3: Patent applications and patents granted of South Korea 1995-2005.

\begin{tabular}{|l|l|l|l|l|l|l|l|l|}
\hline & \multicolumn{9}{|l|}{ Patent applications } & \multicolumn{3}{l|}{ Patents granted } \\
\hline Year & 1995 & 2000 & 2002 & $2005^{*}$ & 1995 & 2000 & 2002 & $2005^{*}$ \\
\hline Number & 78,499 & 116,886 & 106,136 & 160,921 & 12,512 & 34,956 & 45,046 & 73,512 \\
\hline
\end{tabular}

Source: World International Property Organisation WIPO. * Last data available.

\section{Discussion and Conclusions}

The common pattern of Asian success in manufacturing (Japan, South Korea, China...) shows two main characteristics. First, firms are able to integrate and evolve from an interactive learning space to another to get the technological capabilities required for each stage of development. Second, institutional framework and organisational arrangements supported the technological effort.

Like Japan earlier, South Korea imitated and integrated the existing technological systems. Similarly, Chinese firms in the field of mobile telephone technology, entered in several ILS and had joint ventures with Multinational companies to acquire basic manufacturing skills and hone their adaptive capabilities (Von Zedtwitz and Jin, 2007). Unlike Korean firms, however, Chinese firms moved quickly to establish joint ventures and R\&D to keep pace with rapid change of $3 \mathrm{G}$ technology.

South Korean strategies were particularly effective in the assimilation, adaptation and improvement of technologies developed outside Korea. Organisation arrangements and the institutional framework were adapted to fit the technology needs. This experience illustrates, however, that a successful pattern of technological assimilation does not necessarily help in producing new technologies and that contributing to radically new knowledge and technologies requires another set of strategies.

The failure of other developing countries can be attribute to the lack of interactive learning spaces and to the absence of a supportive institutional framework. Firms in these countries rarely have the internal and external resources to integrate and evolve from one interactive learning space to another. Thus, they cannot solve their pressing 
production problems; stagnate at a level of low technological capabilities and insufficient competitiveness in local and international markets. This inability to integrate interactive learning spaces and to evolve among them results from the disjunction of the institutional framework and organisational arrangements from technology evolution.

Accordingly, we propose that technological and economic development is possible only if developing countries make their institutional framework and organisational arrangements compatible with the technology life cycle. More studies of catch up processes are needed to clarify whether it is the political regime, institutional arrangements and culture aspects that determine the accumulation of capabilities and the production of new knowledge or whether the latter depends on each national experience and the history of the various national innovation systems.

\section{References}

Arocena, E. and J. Sutz, (2002). Innovation Systems and Developing Countries, DRUID Working. Paper No 02-05.

Bell, M. (1984). Learning and the Accumulation of Industrial Technological Capacity in Developing Countries. In: Technological Capability in the Third World (M. Fransman and K. King, eds.), pp.187-210. Macmillan, London.

Cooper, C. (1973). Science, technology and development: the political economy of technical advance in underdeveloped countries, London: F. Cass.

Dahlman, C.J., B. Ross-Larsonn, and L.E. Westphal, (1987). Managing Technological Development: Lessons from the Newly Industrializing Countries, World Bank, Staff Working papers. No. 717. 
Dahlman, C. and R.R. Nelson (1995). Social absorption capability, national innovation systems and economic development, in: Social Capability and Long-Term Economic Growth Koo, B. and Perkins, D, eds.), pp. 82-122, Macmillan, London.

Fransman, M. and King, K. (eds.) (1984). Technological Capability in the Third World, Macmillan, London.

Gerschenkron, A. (1962). Economic Backwardness in Historical Perspective: A Book of Essays, Cambridge, MA: Belknap Press of Harvard University Press.

Helleiner, G.K. (1975). The Role of Multinational Corporations in the Less Developed Countries' Trade technology. In: The Economics of Technology Transfer (S. Lall, ed.), pp.161-171, Cheltenham, Edward Elgar.

Herrera, A. (1973). Social Determinants of Science in Latin America: Explicit Science Policy and Implicit Science Policy. In: Science, technology and development: the political economy of technical advance in underdeveloped countries (Cooper, C. ed.), pp.19-38, London F. Cass.

Katz, J.M. (ed.) (1987). Technology Generation in Latin American Manufacturing industries. London, Macmillan.

Kim, L. (1980). Stages of development of industrial technology in a developing country: a model. In: Learning and Innovation in Economic Development (L. Kim), pp 426. Cheltenham, Edward Elgar.

Kim, L. (1993). National System of Industrial Innovation: Dynamics of Capability Building in Korea. In: National Innovation Systems: A Comparative Analysis (R.R. Nelson, (ed.), pp.357-383. New York; Oxford: Oxford university press.

Kim, L. (2000). Korea's National Innovation System in Transition. In: Technology, learning and Innovation (R.R. Nelson L. Kim, eds.), pp. 334-360. Cambridge (GB): Cambridge University Press.

Kim, L. and H. Lee, H (1987). Patterns of Technological Change in a Rapidly Developing Country: A Synthesis. In: Learning and Innovation in Economic Development (L. Kim), pp. 109-124, Cheltenham, Edward Elgar.

Kim, L. and G. Yi (1997). The dynamics of R\&D in Industrial Development: Lessons from Korean Experience. In: Learning and Innovation in Economic Development (L. Kim), pp. 167-82, Cheltenham, Edward Elgar.

Koo, B.H. (1995). Socio-cultural Factors in the Industrialization of Korea. In: Social Capability and Long-Term Economic Growth (B. Koo and D. Perkins, eds.), pp.181-202, Macmillan, London.

Korea Ministry of science and technology, "Science and Technology Policy Directions for the $21^{\text {st }}$ century". http://www.most.go.kr/.

Korea Ministry of Commerce, industry and energy. http://www.mocie.go.kr/main.html

Jones, G. (1971). The role of science and technology in developing countries, London, New York, Published for the International Council of Scientific Unions by Oxford University Press.

Lall, S. (1987). Learning to Industrialize: The Acquisition of Technological Capabilities by India. Macmillan Press, London. 
Lim, Y. (1999). Technology and Productivity, the Korean Way of Learning and catching up. Cambridge, Mass: MIT Press.

Lundvall, B.-Å (1992). National systems of Innovation: Towards a theory of innovation and Interactive learning. London: Pinter.

Mckelvey, M. (1997), Using Evolutionary theory to Define Systems of Innovation. In: Systems of innovation: growth, competitiveness and Employment (C. Edquist and M. Mckelvey eds.), Vol II, pp. 140-162. Cheltenham, UK: Edward Elgar.

Nelson, R.R. (ed.), (1993). National Innovation Systems: A Comparative Analysis. New York; Oxford: Oxford university press.

Nelson, R. R. and S. Winter, (1982). An evolutionary Theory of Economic Change, Cambridge (Mass.) London: The Belknap Press of Harvard, pp. 3-22.

OECD (2005). OECD economic reviews, Korea, October 2005.

OECD (2005). International Trade statistics. www.oecd.org.

OECD (2006). Main Science and Technology Indicators. www.oecd.org.

OECD (2006). STAN database. www.oecd.org.

Perez, C. (2001). Technological change and opportunities for development as a moving target, CEPALR Review 75.

Perez, C. and L. Soete (1988). Catching up in technology: entry barriers and windows of opportunity. In: Technical Change and Economic Theory (Dosi et al., eds.), pp. 458-479, London, Pinter.

Sagasti, F. (2004). Knowledge and Innovation for development, the Sisyphus challenge of the 21 st Century, Cheltenham, Edward Elgar.

Saviotti, P.P (1997), Innovation systems and Evolutionary Theories. In: Systems of innovation: Technologies, Institutions and Organizations (C. Edquist, ed.), chap. 8, pp. 180-199, London; Washington: Pinter.

Song, B-N. (1997). The Rise of The Korean Economy, Hong Kong New York: Oxford University Press.

Toussaint, E. (2006). Banque Mondiale, le coup d'Etat permanent, CADTM, Liège.

Von Zedtwitz, M. and Jin, J. (2007). Process of Technological Capability Development: Cases from China's Mobile Phone Industry. In: Management of Technology: New Directions in technology Management (M. Hachem Sherif, and T.M. Khalil, eds.), pp 311-326, Amsterdam, Elsevier.

Westphal, L.E, L. Kim, and C. Dahlman, (1985). Reflections on the Republic of Korea's Acquisition of Technological Capability. In: International Technology Transfer: Concepts, Measures, and Comparisons (N. Rosenberg and C. Frischtak, eds.), pp. 167-221. New York, Praeger.

Westphal, L.E, Y.W Rhee, and G. Pursell, (1985). Sources of Technological Capability in South Korea. In: Technological capability in the third world (K. King and M. Fransman eds.), pp.279-300, London,, Macmillan.

World Bank (2007). World Development Indicators Database. web.worldbank.org

World International Property Organisation. (2007). Patents Data. www.wipo.int 